\title{
Taxonomy and DNA Sequencing of Crematogaster coriaria Mayr, 1872 (Hymenoptera: Formicidae), with Redescriptions of the Worker, Queen, and Male Castes
}

\author{
Shingo Hosoishi and Kazuo Ogata \\ Institute of Tropical Agriculture, Kyushu University, 6-10-1 Hakozaki, Higashi-ku, Fukuoka 812-8581, Japan \\ Correspondence should be addressed to Shingo Hosoishi; hosoishi@gmail.com
}

Received 30 July 2015; Accepted 20 September 2015

Academic Editor: Jacques Hubert Charles Delabie

Copyright (C) 2015 S. Hosoishi and K. Ogata. This is an open access article distributed under the Creative Commons Attribution License, which permits unrestricted use, distribution, and reproduction in any medium, provided the original work is properly cited.

Crematogaster coriaria Mayr, 1872, is revised based on the nest series samples. The following new synonymies are proposed: $C$. coriaria Mayr, $1872=$ C. coriaria fraudatrix Forel, 1911 syn. nov. $=$ C. spengeli Forel, 1912 syn. nov. $=$ C. spengeli taipingensis Forel, 1913 syn. nov. Worker, queen, and male castes of C. coriaria Mayr, 1872, are redescribed. The polymorphism of C. coriaria Mayr, 1872, was also discussed. DNA sequences were generated for C. coriaria Mayr, 1872, using an amplification of second half region of the mitochondrial gene COI with a total of $711 \mathrm{bp}$. The interspecific COI divergence is $17.4 \%$ for C. coriaria Mayr, 1872 , and $C$. modiglianii Emery, 1900

\section{Introduction}

Crematogaster coriaria Mayr, 1872, was described by Mayr [1] based on the worker specimens from Borneo, Malaysia. One following subspecies of C. coriaria Mayr, 1872, has been recognized: C. coriaria fraudatrix Forel, 1911, by Forel [2] based on the workers from Sumatra, Indonesia. This species had been classified into the former subgenus Paracrema but presently assigned to the subgenus Crematogaster [3].

Crematogaster coriaria Mayr, 1872, is distributed in Malaysia (Peninsula, Borneo) and Indonesia (Sumatra, Java) and has been reported from several localities in the literatures [4-6]. This species inhabits well-developed forests and nests in the dead woods.

This species is relatively roughly distinguished from other Crematogaster fauna by 4-segmented antennal club and weak sculptured body surface. However, due to the strong polymorphism, the taxonomy of this species has been confused as follows. This species is distinctly polymorphic in size and sculpture, causing some synonymies in some species and subspecies. Crematogaster coriaria Mayr, 1872, has relatively smooth surface of body in smaller workers but develops the rugulae and sculpture in larger workers.
The present paper aims to revise the synonymies based on the nest series samples. Such samples can reveal morphological continuities within conspecific taxa.

As in other ant genera, taxonomy of the genus Crematogaster has been generally improved based on the worker caste [7]. The sexual forms are poorly investigated because of the rarity of sexual castes in the collections and unexplored characters in the genus (but see $[8,9])$. The present paper describes queen and male castes of C. coriaria Mayr, 1872, and it will provide a starting point for taxonomic studies to find the valid characters.

Molecular approaches including DNA barcodes have been recently used in biodiversity studies of ant species [10] and are used as an additional and powerful method in integrative taxonomy [11]. They can thus provide a useful reference for the identification of Asian Crematogaster species. Therefore, cytochrome oxidase I (COI) sequence data from Crematogaster coriaria Mayr, 1872, is also generated and compared with the closely related species, C. modiglianii Emery, 1900. Our analysis included the $3^{\prime}$ region of COI region.

In the present paper, based on our examination of type materials of almost all of the forms under consideration 
and nontype specimens including nest series samples, we revise their names and solve synonymy of taxa related to the species. In addition, this study redescribes the queen and male castes of the species and then contributes toward the taxonomy on sexual forms of Crematogaster ants in specieslevel identification. The sequence data provide additional information for the species.

\section{Materials and Methods}

2.1. Sources of Material. Type and nontype specimens were examined and/or deposited in the collections listed below. Codes for public institutions generally follow those in [12].

KUEC: Institute of Tropical Agriculture, Kyushu University, Fukuoka, Japan.

MHNG: Musee d'Histoire Naturelle, Geneva, Switzerland.

NHMW: Naturhistorisches Museum, Wien, Austria.

2.2. Observation. Most observations were made at various magnifications on a Leica M205C stereomicroscope. Images were taken using a Canon EOS 50D with Canon MP-E $65 \mathrm{~mm}$ 1-5x Macro Lens and then processed using Combine ZM.

2.3. Measurements and Indices. Measurements were made under a Leica M205C stereomicroscope using micrometers. All measurements are expressed in millimeters, recorded to the second decimal place. The measurements for petiole and postpetiole follow [13] and those for queen and male specific measurements follow [8].

Data were plotted on log-log scales and regression lines calculated for workers using $\mathrm{R}$ version 2.14.2.

Head width (HW): maximum width of head in fullface view, excluding the eyes, in the worker and queen castes, but measured including the eyes in the male caste.

Head Length (HL): perpendicular distance from vertex margin to line tangent anteriormost projections of clypeus in full-face view.

Cephalic Index (CI): HW/HL $\times 100$.

Scape length (SL): length of the first antennal segment, excluding the neck and basal condyle.

Scape Index (SI): SL/HW $\times 100$.

Eye Length (EL): maximum length of the compound eye.

Pronotal Width (PW): maximum width of the pronotum in dorsal view in the worker caste.

Weber's length of the mesosoma (WL): diagonal length, measured in lateral view from the anterior margin of the pronotum (excluding the collar) to the posterior extremity of the propodeal lobe.

Propodeal Spine Length (PSL): measured from tip of propodeal spine to closest point on outer rim of propodeal spiracle in the worker caste but measured from tip of propodeal spine to propodeal declivity in lateral view in the queen caste.

Petiole Length $(\mathrm{PtL})$ : length of the petiole in lateral view.

Petiole Width (PtW): maximum width of petiole in dorsal view.

Petiole Height $(\mathrm{PtH})$ : height of the petiole in lateral view.

Postpetiole Length $(\mathrm{PpL})$ : length of the postpetiole in lateral view (see [13, Figure 2]).

Postpetiole Width (PpW): maximum width of postpetiole in dorsal view, excluding the helcium.

Petiole Height Index (PtHI): PtH/PtL $\times 100$.

Petiole Width Index (PtWI): PtW/PtL $\times 100$.

Postpetiole Width Index (PpWI): PpW/PpL $\times 100$.

Waist Index (WI): PpW/PtW $\times 100$.

Queen and male specific measurements [8] are as follows:

Mesonotal width (MSNW): maximum width of mesonotum in dorsal view.

Mesonotal length (MSNL): maximum length of mesonotum in dorsal view.

Mesonotal Index (MSNI): MSNW/MSNL $\times 100$.

2.4. Genetic Analysis. Genomic DNA was extracted from tissues rich in mitochondria (e.g., legs) using a DNeasy Blood \& Tissue kit (Qiagen, Maryland, USA). A 711 bp region of the mitochondrial genome, $3^{\prime}$ region of the cytochrome oxidase I (COI), was amplified via the polymerase chain reaction (PCR) using primers "Jerry" $5{ }^{\prime}$-CAACATTTATTTTGATTTTTTGG-3' and "Pat" $5^{\prime}$-TCCAATGCACTAATCTGCCATATTA-3' [14]. Reactions were carried out at $10 \mu \mathrm{L}$ volumes in a PCR Thermal Cycler MP (TaKaRa Bio Inc.) under the following conditions: a first cycle of $94^{\circ} \mathrm{C}$ for $1 \mathrm{~min}$, followed by 5 cycles of $94^{\circ} \mathrm{C}$ for $1 \mathrm{~min}$, annealing at $48^{\circ} \mathrm{C}$ for $90 \mathrm{~s}$, and $72^{\circ} \mathrm{C}$ for $90 \mathrm{~s}$, and then 30 cycles of $94^{\circ} \mathrm{C}$ for $1 \mathrm{~min}$, annealing at $51^{\circ} \mathrm{C}$ for $90 \mathrm{~s}$, and finally $72^{\circ} \mathrm{C}$ for $90 \mathrm{~s}$ for the COI.

PCR products were visualized on a $1 \%$ agarose E-Gel 96-well system (Invitrogen) and then purified with $1.0 \mu \mathrm{L}$ of ExoSAP-IT (GE Healthcare Life Sciences). All products were sequenced in both directions using BigDye Terminator v3.1 (Applied Biosystems) on an ABI 3100 Avant DNA Sequencer (Applied Biosystems) at the Faculty of Science, Kyushu University, Fukuoka. It is noted that these sequences are not DNA barcoding region. DNA sequence data for one individual of Crematogaster coriaria Mayr, 1872, and closely related species, C. modiglianii Emery, 1900, were thus generated and deposited at DNA Data Base of Japan, DDBJ (with accession numbers: LC068833, for C. coriaria Mayr, 1872, and LC068834 for C. modiglianii Emery, 1900). Crematogaster coriaria Mayr, 1872, was sequenced from one nest series (SH10-Mal-85) from Ulu Gombak, Malaysia (Peninsular Malaysia), and C. modiglianii Emery, 1900, from 


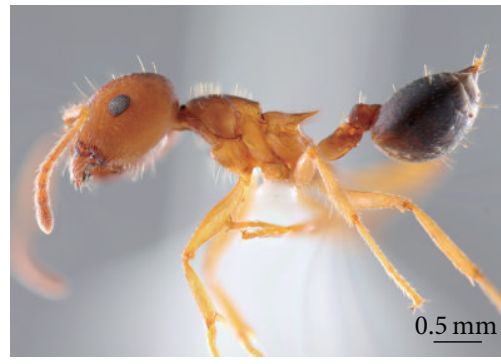

(a)

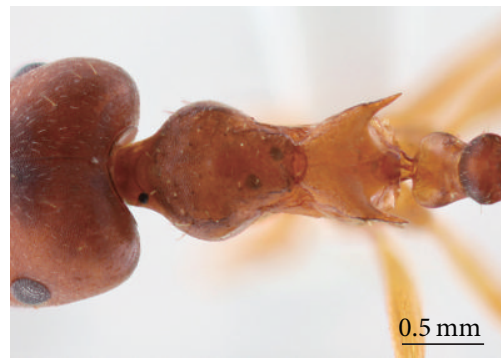

(c)

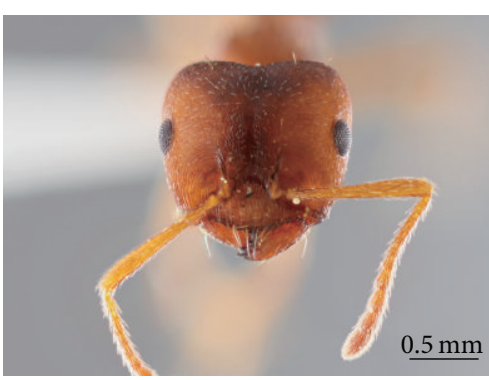

(b)

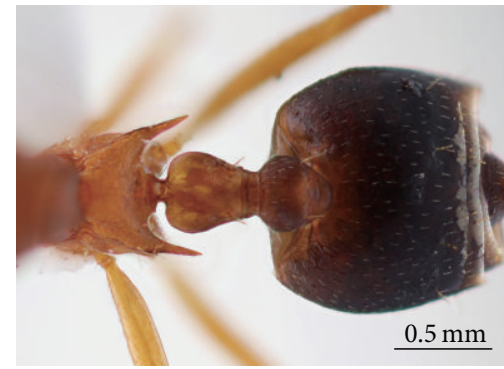

(d)

FIGURE 1: Crematogaster coriaria Mayr, 1872, worker. (a)-(d) Large worker (HW 1.39; WL 1.52) (Ulu Gombak, Selangor, Malaysia): (a) body in lateral view; (b) full-face view of head; (c) dorsal view of mesosoma; (d) petiole and postpetiole in dorsal view.

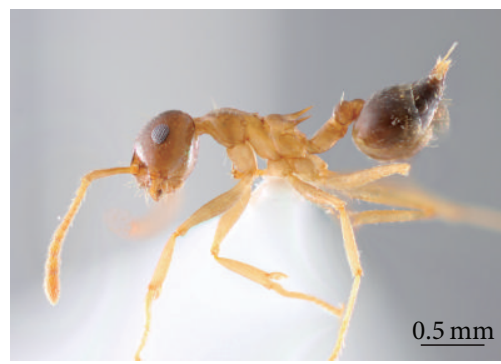

(a)

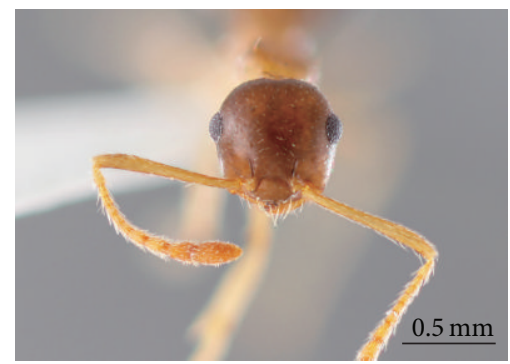

(b)

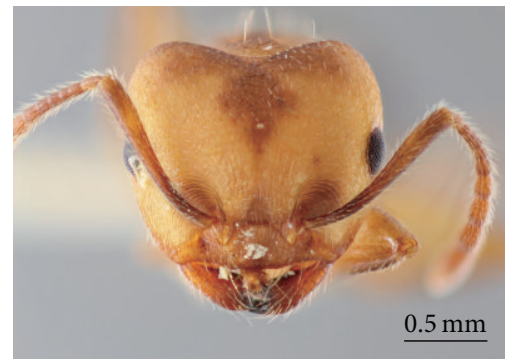

(c)

FIGURE 2: Crematogaster coriaria Mayr, 1872, worker. (a)-(c) Small worker (HW 0.64; WL 0.88) (Ulu Gombak, Selangor, Malaysia): (a) body in lateral view; (b) full-face view of head; (c) large worker having ocelli (HW 1.63; WL 1.58) (Cikaniki, Halimun, Java, Indonesia).

one nest series (SH10-Mal-18) from Ulu Gombak, Malaysia (Peninsular Malaysia). Contigs were assembled using Vector NTI Advance TM ver. 11 (Invitrogen Corp.) and subsequently aligned by eye. Genetic distances were estimated using the Kimura-2-parameter [15] distances with MEGA 5 [16].

\section{Results}

\subsection{Taxonomy}

Crematogaster coriaria Mayr, 1872 (see Figures 1-4). Crematogaster coriaria Mayr, 1872: 154 [1]. LECTOTYPE worker (by present designation) and three paralectotype workers from 


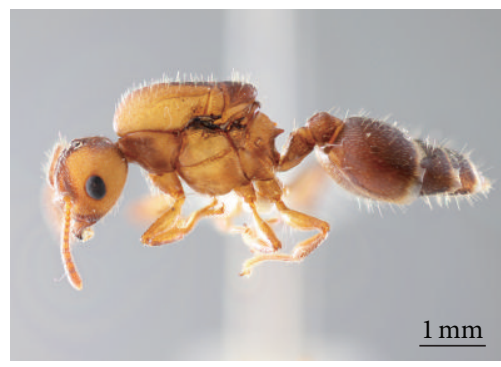

(a)

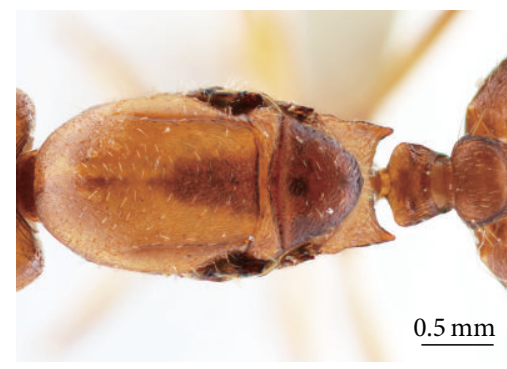

(c)

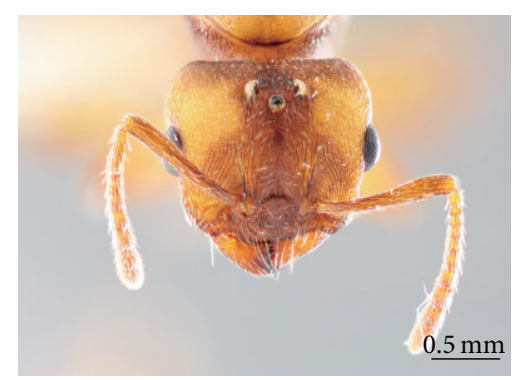

(b)

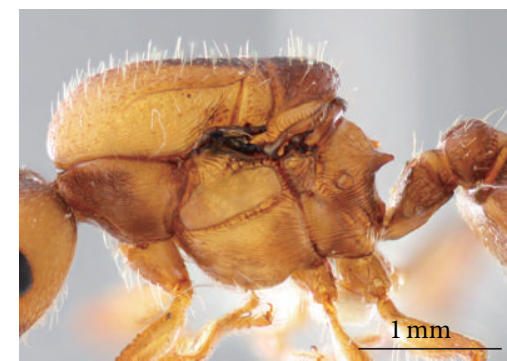

(d)

Figure 3: Crematogaster coriaria Mayr, 1872, queen: (a) body in lateral view; (b) full-face view of head; (c) dorsal view of mesosoma; (d) lateral view of mesosoma, petiole, and postpetiole.

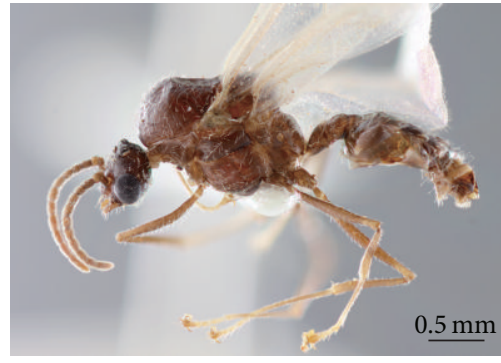

(a)

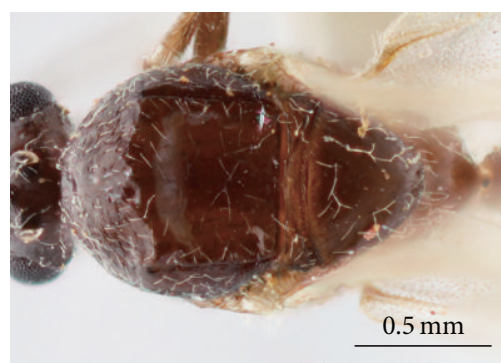

(c)

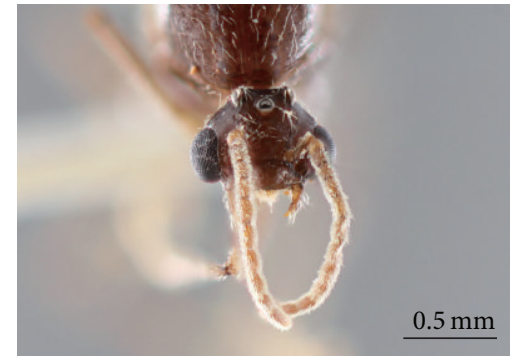

(b)

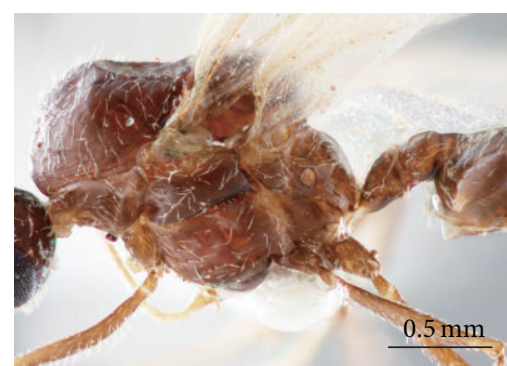

(d)

Figure 4: Crematogaster coriaria, Mayr, 1872, male: (a) body in lateral view; (b) full-face view of head; (c) dorsal view of mesosoma; (d) lateral view of mesosoma, petiole, and postpetiole.

MALAYSIA: Borneo, Sarawak, 1865-66 (G. Doria) (NHMW, MHNG) (examined). Combination in C. (Paracrema) by Emery, 1922: 155 [17]; in C. (Crematogaster) by Blaimer, 2012: $55[3]$.

Crematogaster coriaria subsp. fraudatrix Forel, 1911: 376 [2]. LECTOTYPE worker (by present designation) from INDONESIA: Sumatra. (Bluntschli) (MHNG) (examined).
Combination in C. (Paracrema) by Emery, 1922: 155 [17]. syn. nov.

Crematogaster spengeli Forel, 1912: 56 [18]. LECTOTYPE worker (by present designation) from INDONESIA: Sumatra, Indrapura. (Tritschler). (MHNG) (examined). Combination in C. (Paracrema) by Santschi, 1918: 182 [19]; in C. (Crematogaster) by Blaimer, 2012: 55 [3]. syn. nov. 
Crematogaster spengeli r. taipingensis Forel, 1913: 75, figure $\mathrm{V}$, [20]. LECTOTYPE worker (top specimen of three on one pin) (by present designation) and two paralectotype workers from MALAYSIA: Taiping, Maxwell Hill. (MHNG) and three paralectotype workers from MALAYSIA: Bandar Baru (MHNG) (examined). Combination in C. (Paracrema) by Emery, 1922: 156 [17]. syn. nov.

Worker Measurements and Indices. HW 0.64-1.63; HL 0.681.49; CI 93-110; SL 0.81-1.19; SI 73-128; EL 0.18-0.30; PW 0.43-0.88; WL 0.88-1.58; PSL 0.19-0.37; PtL 0.24-0.46; PtW 0.25-0.52; PtH 0.16-0.32; PpL 0.14-0.32; PpW 0.25-0.48; PtHI 60-90; PtWI 91-131; PpWI 144-200; WI 88-107 (fiftythree workers measured).

General Description of Worker. Workers with pronounced size polymorphism.

Head subquadrate in full-face view, with weakly concave posterior margin, angular posterior corners, and subparallel sides; posterior portion developed in large workers (Figures 1(b) and 2(c)). Ocelli rarely developed in large workers (Figure 2(c)). Occipital carinae developed. Mandible with four teeth in small workers and five in large workers, apical and subapical teeth large. Anterior margin of clypeus convex with slightly impressed median portion; anterolateral margins of clypeus protruded anteriorly; posterior margin of clypeus rounded between frontal lobes. Frontal carinae almost parallel. Antennae 11 segmented; relative scape length variable in several worker size; antennal club 4-segmented. Scape exceeding posterior corner of head. Compound eyes distinctly projecting beyond lateral margins of head in fullface view in small workers (Figure 2(b)), but not distinctly projecting in large workers (Figures $1(\mathrm{~b})$ and $2(\mathrm{c})$ ).

Pronotum and mesonotum almost fused without defined suture, rarely promesonotal suture present in large workers. Posterior margins of mesonotum forming triangle-shaped process in lateral view in small workers (Figure 2(a)), but mesonotal dorsum forming flat outline in large workers (Figure 1(a)). Mesothoracic spiracle reduced to form small pit dorsoventrally. Metapleural gland opening slit-shaped. Propodeal spiracle elliptical, situated at posterolateral corners, touching metapleural gland bulla. Metanotal groove straight in dorsal view, deep and forming concave region between mesonotum and propodeum. In dorsal view, feeble longitudinal rugulae connecting between mesonotum and propodeum; the boundary distinct. Propodeal spines developed long.

Petiole scoop shaped, but flattened with convex sides or broader anteriorly, longer than broad; spiracle situated anteriorly midportion between dorsal and ventral margin of petiole in lateral view, directed laterally. Postpetiole without distinctly longitudinal median sulcus, but bilobed behind in large workers; spiracle situated anteriorly on lateral surface.

Posterior half of head sculptured without rugulae; gena with rugulae on surrounding antennal sockets. Clypeus with abundant longitudinal rugulae in large workers (Figures 1(b) and 2(c)), but weakly punctuated in small workers (Figure 2(b)). Promesonotum weakly punctuated. Lateral surface of pronotum smooth and shining. Mesopleuron densely sculptured. Anterodorsal surface of propodeum generally sculptured. Lateral surface of propodeum smooth and shining. Dorsal surface of petiole smooth and shining. Lateral surface of petiole weakly punctuated. Dorsal surface of postpetiole sculptured. Lateral surface of postpetiole generally smooth and shining.

Standing pilosity sparse. Dorsal face of head with some pairs of long and erect setae. Clypeus with some pairs of erect setae. Anterior clypeal margin with two pairs of long setae mixed with short setae laterally. Mesonotal dorsum with sparse erect setae. Petiole with one pair of suberect setae posteriorly. Postpetiole with one pair of suberect setae posteriorly. Fourth abdominal tergite with appressed setae and sparse erect setae.

Body color yellow-brown.

Queen Measurements and Indices. HW 1.54-1.59; HL 1.391.42; CI 111-112; SL 1.09-1.16; SI 71-73; EL 0.40-0.43; MSNW 1.38-1.39; MSNL 2.38-2.48; MSNI 56-58; WL 2.77-2.78; PSL 0.19-0.20; PtL 0.55-0.56; PtW 0.65-0.66; PtH 0.47-0.49; PpL 0.38-0.43; PpW 0.65-0.69; PtHI 85-88; PtWI 118; PpWI 160171; WI 100-105 (two queens measured).

Description of Queen. With worker character conditions, except as follows.

Masticatory margin of mandibles with five teeth. Antennal scapes reaching posterior margin of head.

Mesosoma slender (MSNI 56-58, WL 2.77-2.78); mesoscutum in dorsal view about 2 times longer than broad. Propodeal spines short and stout. Petiolar spiracles situated below lateral tubercles. Subpetiolar process absent. Postpetiolar spiracles situated at lateral tubercles.

Dorsal surface of head with longitudinal rugulae, but posterior half weakly striated (Figure 3(b)). Mandibles generally smooth. Clypeus with abundant longitudinal rugulae. Mesonotum weakly shining, but weakly sculptured (Figure 3(c)). Lateral surface of pronotum and mesopleuron with feeble longitudinal rugulae (Figure 3(d)). Dorsal surface of propodeum with longitudinal rugulae (Figure 3(c)). Lateral surface of propodeum with distinct longitudinal rugulae (Figure 3(d)). Dorsal surface of petiole weakly sculptured (Figure 3(c)). Lateral surface of petiole sculptured (Figure 3(d)). Dorsal and lateral surface of postpetiole sculptured (Figure 3(c)).

Dorsal surface of head with sparse erect setae and abundant appressed setae. Anterior clypeal margin with one to two pairs of long setae mixed with short setae laterally. Scape with decumbent to appressed long setae. Mesonotal dorsum with erect setae sparsely. Fourth abdominal tergite with erect setae and appressed setae sparsely.

Male Measurements and Indices. HW 0.80; HL 0.58; CI 137; SL 0.15; SI 19; EL 0.29; MSNW 0.89; MSNL 1.46; MSNI 61.2; WL 1.54; PSL 0; PtL 0.27; PtW 0.28; PtH 0.23; PpL 0.18; PpW 0.32; PtHI 84; PtWI 101; PpWI 178; WI 116 (one male measured).

Description of Male. Mandibles very short, masticatory margin with two teeth, one large apical, but a blunt second lobelike. Clypeus weakly convex with almost straight median. 


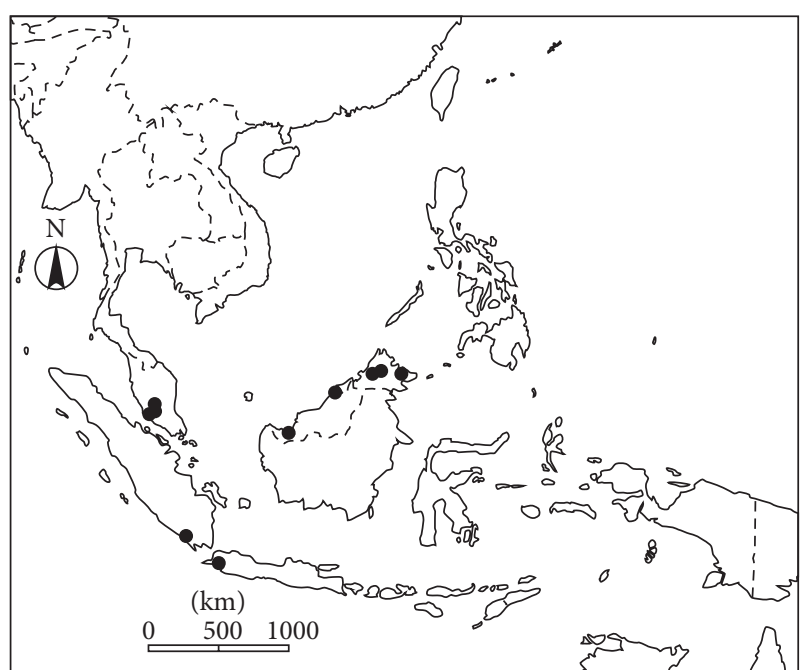

FIGURE 5: Distribution map of Crematogaster coriaria Mayr, 1872, specimens examined during this study.

Compound eyes large and protruding, midline of eyes situated well below midline of head. Antennae 12-segmented; flagellar segment longer than broad in apical to second basal segments (antennal segments III to XII). Head much wider than long (CI 137). In full-face view ocellar triangle situated at posterior head margin and elevated with respect to rest of face. Occipital carinae distinct.

Mesonotum in dorsal view longer than broad (MSNI 61.2); scutellum in dorsal view broadly tapering from anterior to posterior end, dorsoposteriorly rounded. Metanotum not protruding from below scutellum. Dorsal face of propodeum almost as long as posterior face. Propodeal spines absent. Petiole in dorsal view oval, weakly convex laterally, in lateral view anteriorly tapering. Subpetiolar process absent. Postpetiole almost round, but weakly bilobed posteriorly, lacking median impression.

Head sculpture shiny to rugulose (Figure 4(b)). Lower genal area surrounding antennal sockets with distinct rugulae. Mandibles striated with longitudinal rugulae. Clypeus shiny, but weakly sculptured. Mesoscutum generally smooth and shining, but anterior face with feeble rugulae (Figure 4(c)). Mesopleuron generally smooth and shining (Figure 4(d)).

Dorsal surface of head with suberect setae sparsely. Mesosoma with decumbent setae sparsely; propodeum with erect setae sparsely. Petiole and postpetiole with erect to decumbent setae sparsely. Fourth abdominal tergite with suberect to decumbent setae sparsely.

Color brown.

Distribution and Biology. This species is distributed in Malaysia (Peninsula, Borneo) and Indonesia (Sumatra, Java) (Figure 5). This species inhabits well-developed forests and nests in the dead woods.

Remarks. This species is similar to C. modiglianii Emery, 1900 , but can be distinguished by the rugulae surrounding

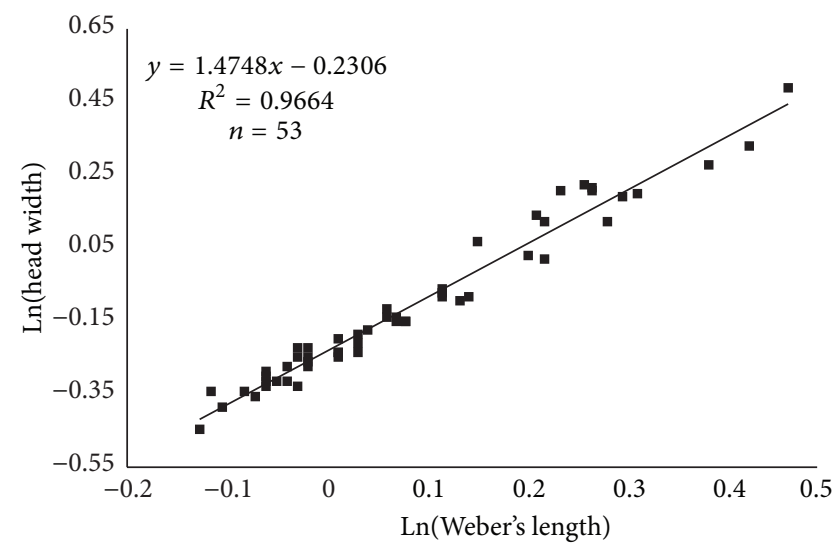

FIGURE 6: Relation between natural logarithms of Weber's length (WL) and head width (HW) in workers $(n=53)$ of $C$. coriaria Mayr, 1872 .

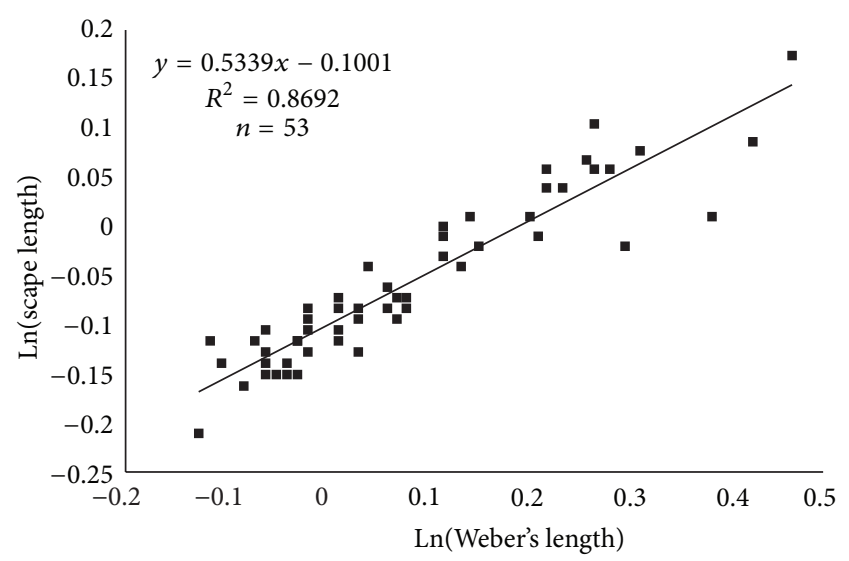

FIGURE 7: Relation between natural logarithms of Weber's length (WL) and scape length (SL) in workers $(n=53)$ of $C$. coriaria Mayr, 1872 .

antennal sockets, mesonotal dorsum without a ridge on the median in the worker caste. Crematogaster coriaria Mayr, 1872, and C. modiglianii Emery, 1900, are geographically sympatric in the Peninsular Malaysia, Borneo, and Sumatra [21]. The COI divergence between C. coriaria Mayr, 1872 (Ulu Gombak specimen), and C. modiglianii Emery, 1900 (Ulu Gombak specimen), was relatively high (17.4\% K2P distance), suggesting that the two taxa are distinct species.

The relation between Weber's length and head width showed a monophasic allometric growth (Figure 6). The slope of the regression line was greater than $1(t=35.4$, $p<0.01$ ), suggesting that large workers had proportionally wider head capsules than small workers. The relation between Weber's length and scape length also showed a monophasic allometric growth (Figure 7). The slope of regression line was lower than $1(t=17.6, p<0.01)$, suggesting that large workers had proportionally shorter antennal scapes than small workers.

Specimens Examined. MALAYSIA: 1 worker, Mager Trail, Fraser's Hill $\left(3^{\circ} 42^{\prime} \mathrm{N}, 101^{\circ} 44^{\prime} \mathrm{E}\right)$, 15. iii. 2005 (2005c 39$)$ 
(S. Hosoishi) (KUEC); 1 worker, Bunga Buah, ca $1000 \mathrm{~m}$ alt., nr Genting H. L., Malay Pen. $\left(3^{\circ} 25^{\prime} \mathrm{N}, 101^{\circ} 47^{\prime} \mathrm{E}\right), 6$. vii. 1999 (Sk. Yamane) (KUEC); 9 workers, 1 male, Bunga Buah, ca. $1000 \mathrm{~m}$ alt., nr Genting H. L., Malay Pen. $\left(3^{\circ} 25^{\prime} \mathrm{N}\right.$, $101^{\circ} 47^{\prime} \mathrm{E}$ ), 6. vii. 1999 (MA99-SKY-15) (Sk. Yamane) (KUEC); 3 workers, Ulu Gombak, Selangor $\left(3^{\circ} 19^{\prime} \mathrm{N}, 101^{\circ} 45^{\prime} \mathrm{E}\right)$, 2. xii. 2005 (SH05-Mal-13) (S. Hosoishi) (KUEC); 8 workers, Ulu Gombak, Selangor $\left(3^{\circ} 25^{\prime} \mathrm{N}, 101^{\circ} 47^{\prime} \mathrm{E}\right.$ ), 17. iii. 2009 (SH09Mal-143) (S. Hosoishi) (KUEC); 3 workers, Poring (600$700 \mathrm{~m}$ alt.), Sabah, Borneo, E. Malaysia $\left(6^{\circ} 02^{\prime} \mathrm{N}, 116^{\circ} 42^{\prime} \mathrm{E}\right)$, 8. i. 1998 (F. Yamane) (KUEC); 8 workers, 2 queens, Danum Valley, Sabah, Borneo, E. Malaysia $\left(4^{\circ} 33^{\prime} \mathrm{N}, 117^{\circ} 08^{\prime} \mathrm{E}\right), 1$. v. 2000 (CB-00-15) (C. Bruhl) (KUEC); 1 worker, Danum Valley, Sabah, Borneo, E. Malaysia $\left(4^{\circ} 33^{\prime} \mathrm{N}, 117^{\circ} 08^{\prime} \mathrm{E}\right)$, 1. v. 2000 (C. Bruhl) (KUEC); 13 workers, Mahua Waterfall, Crocker Range, Sabah $\left(5^{\circ} 45^{\prime} \mathrm{N}, 116^{\circ} 30^{\prime} \mathrm{E}\right)$, 4. xi. 2000 (B. T. Viet) (KUEC); 2 workers, 8 ha plot, Tower Reg., Lambir, Miri, Sarawak, E. Malaysia $\left(4^{\circ} 11^{\prime} \mathrm{N}, 114^{\circ} 02^{\prime} \mathrm{E}\right), 27$. viii. 1994 (T. Itioka \& T. Yumoto) (KUEC); 2 workers, 8 ha plot, Tower Reg., Lambir, Miri, Sarawak, E. Malaysia $\left(4^{\circ} 11^{\prime} \mathrm{N}, 114^{\circ} 02^{\prime} \mathrm{E}\right), 26$. viii. 1994 (T. Itioka \& T. Yumoto) (KUEC); INDONESIA: 8 workers, around Cikaniki (ca. $1050 \mathrm{~m}$ alt.), G. Halimun NP, E. Java $\left(6^{\circ} 43^{\prime} \mathrm{S}, 106^{\circ} 27^{\prime} \mathrm{E}\right)$, 14. viii. 2002 (JV02-SKY-07) (Sk. Yamane) (KUEC); 4 workers, Cikaniki (1050-1250 m alt.), G. Halimun, W. Java $\left(6^{\circ} 43^{\prime} \mathrm{S}, 106^{\circ} 27^{\prime} \mathrm{E}\right.$ ), 25. i. 2004 (JV04SKY-25) (Sk. Yamane) (KUEC); 2 workers, Bodong Jaya, Sumberjaya, Lampung Barat, S. Sumatra $\left(5^{\circ} 10^{\prime} \mathrm{S}, 104^{\circ} 07^{\prime} \mathrm{E}\right)$, 18. ix. 2007 (SU07-SKY-200: secondary forest) (Sk. Yamane) (KUEC); 6 workers, Bodong Jaya, Sumberjaya, Lampung Barat, S. Sumatra $\left(5^{\circ} 10^{\prime}\right.$ S, $\left.104^{\circ} 07^{\prime} \mathrm{E}\right), 16$. ix. 2007 (SU07-SKY154) (Sk. Yamane) (KUEC); 4 workers, Bodong Jaya, Sumberjaya, Lampung Barat, S. Sumatra $\left(5^{\circ} 10^{\prime} \mathrm{S}, 104^{\circ} 07^{\prime} \mathrm{E}\right)$, 16. ix. 2007 (Gede) (KUEC); 2 workers, Bodong Jaya, Sumberjaya, Lampung Barat, S. Sumatra $\left(5^{\circ} 10^{\prime} \mathrm{S}, 104^{\circ} 07^{\prime} \mathrm{E}\right)$, 17. ix. 2007 (Sk. Yamane) (KUEC).

\section{Conflict of Interests}

The authors declare that there is no conflict of interests regarding the publication of this paper.

\section{Acknowledgments}

The authors would like to thank Seiki Yamane for collecting specimens and for his continuing support. The authors are grateful to the following persons for loans of material or access to museum collections: Bernhard Merz (MHNG) and Dominique Zimmermann (NHMW). The authors would like to thank Rosli Hashim who provisioned for their collection trips. The authors would like to thank the ANeT members for encouragement. This work was supported in part by JSPS KAKENHI (grant-in-aid for Scientific Research (C)) Grant no. 26440221 and KAKENHI (grant-in-aid for Scientific Research (B)) Grant no. 26304014.

\section{References}

[1] G. Mayr, Formicidae Borneenses collectae a J. Doria et O. Beccari in territorio Sarawak annis 1865-1867, vol. 2, Annali del Museo Civico di Storia Naturale di Genova, 1872.
[2] A. Forel, "Fourmis nouvelles ou intéressantes", Bulletin de la Société Vaudoise des Sciences Naturelles, vol. 47, pp. 331-400, 1911.

[3] B. B. Blaimer, "A subgeneric revision of Crematogaster and discussion of regional species-groups (Hymenoptera: Formicidae)," Zootaxa, vol. 3482, pp. 47-67, 2012.

[4] K. Eguchi and S. Yamane, "Species diversity of ants (Hymenoptera, Formicidae) in a lowland rainforest, Northwestern Borneo," New Entomologist, vol. 52, pp. 49-59, 2003.

[5] W. Jaitrong and J. Nabhitabhata, "A list of known ant species of Thailand (Formicidae: Hymenoptera)," The Thailand Natural History Museum Journal, vol. 1, pp. 9-54, 2005.

[6] M. Pfeiffer, D. Mezger, S. Hosoishi, B. E. Yahya, and R. Kohout, "The formicidae of Borneo (Insecta: Hymenoptera): a preliminary species list," Asian Myrmecology, vol. 4, no. 1, pp. 9-58, 2011.

[7] S. Hosoishi and K. Ogata, "A taxonomic revision of the Asian endemic subgenus Physocrema of the genus Crematogaster (Hymenoptera: Formicidae)," Zootaxa, vol. 2062, pp. 15-36, 2009.

[8] A. Forel, "Nouvelles espèces de formicides de Madagascar. (Récoltées par M. Sikora)," Annales de la Société Entomologique de Belgique, vol. 36, pp. 516-535, 1892.

[9] B. B. Blaimer, "Taxonomy of the Crematogaster degeeri-speciesassemblage in the Malagasy region (Hymenoptera: Formicidae)," European Journal of Taxonomy, vol. 51, pp. 1-64, 2013.

[10] M. A. Smith, B. L. Fisher, and P. D. N. Hebert, "DNA barcoding for effective biodiversity assessment of a hyperdiverse arthropod group: the ants of Madagascar," Philosophical Transactions of the Royal Society of London, Series B: Biological Sciences, vol. 360, no. 1462, pp. 1825-1834, 2005.

[11] B. C. Schlick-Steiner, F. M. Steiner, B. Seifert, C. Stauffer, E. Christian, and R. H. Crozier, "Integrative taxonomy: a multisource approach to exploring biodiversity," Annual Review of Entomology, vol. 55, pp. 421-438, 2010.

[12] C. R. F. Brandão, "Major regional and type collections of ants (Formicidae) of the World and sources for the identification of ant species," in Ants: Standard Methods for Measuring and Monitoring Biodiversity, D. Agosti, J. D. Majer, L. E. Alonso, and T. R. Chultz, Eds., pp. 172-185, Smithonian Institution Press, Washington, DC, USA, 2000.

[13] J. T. Longino, "The Crematogaster (Hymenoptera, Formicidae, Myrmicinae) of Costa Rica," Zootaxa, vol. 151, pp. 1-150, 2003.

[14] C. Simon, F. Frati, A. Beckenbach, B. Crespi, H. Liu, and P. Flook, "Evolution, weighting, and phylogenetic utility of mitochondrial gene sequences and a compilation of conserved polymerase chain reaction primers," Annals of the Entomological Society of America, vol. 87, no. 6, pp. 651-701, 1994.

[15] M. Kimura, "A simple method for estimating evolutionary rates of base substitutions through comparative studies of nucleotide sequences," Journal of Molecular Evolution, vol. 16, no. 2, pp. 111$120,1980$.

[16] K. Tamura, D. Peterson, N. Peterson, G. Stecher, M. Nei, and S. Kumar, "MEGA5: molecular evolutionary genetics analysis using maximum likelihood, evolutionary distance, and maximum parsimony methods," Molecular Biology and Evolution, vol. 28, no. 10, pp. 2731-2739, 2011.

[17] C. Emery, "Hymenoptera, Fam. Formicidae, subfam. Myrmicinae," in Genera Insectorum, vol. 174, pp. 95-206, Forgotten Books, London, UK, 1922.

[18] A. Forel, "H. Sauter's Formosa-Ausbeute: Formicidae," Entomologische Mitteilungen, vol. 1, pp. 45-81, 1912. 
[19] F. Santschi, "Sous-genres et synonymies de Cremastogaster," Bulletin de la Société Entomologique de France, vol. 1918, pp. 182$185,1918$.

[20] A. Forel, "Wissenschaftliche Ergebnisse einer Forschungsreise nach Ostindien, ausgeführt im Auftrage der Kgl. Preuss. Akademie der Wissenschaften zu Berlin von H. v. ButtelReepen. 2. Ameisen aus Sumatra, Java, Malacca und Ceylon. Gesammelt von Herrn Prof. Dr. v. Buttel-Reepen in den Jahren 1911-1912," Zoologische Jahrbücher. Abteilung für Systematik, Geographie und Biologie der Tiere, vol. 36, pp. 1-148, 1913.

[21] S. Hosoishi, S. Yamane, and K. Ogata, "An evaluation of infraspecific names in Crematogaster (Paracrema) modiglianii based on nest series (Hymenoptera: Formicidae)," Myrmecological News, vol. 14, pp. 123-128, 2010. 

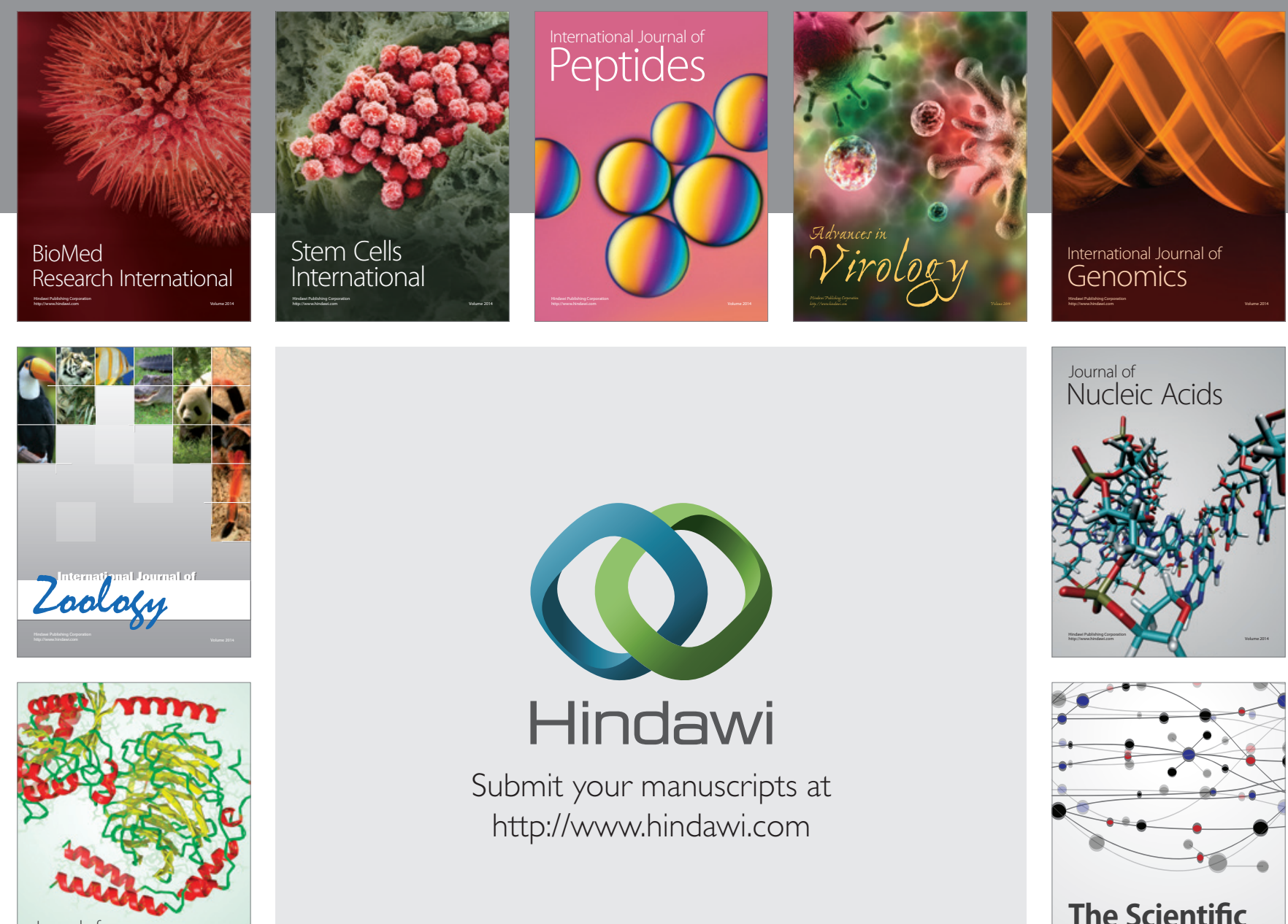

Submit your manuscripts at

http://www.hindawi.com

Journal of
Signal Transduction
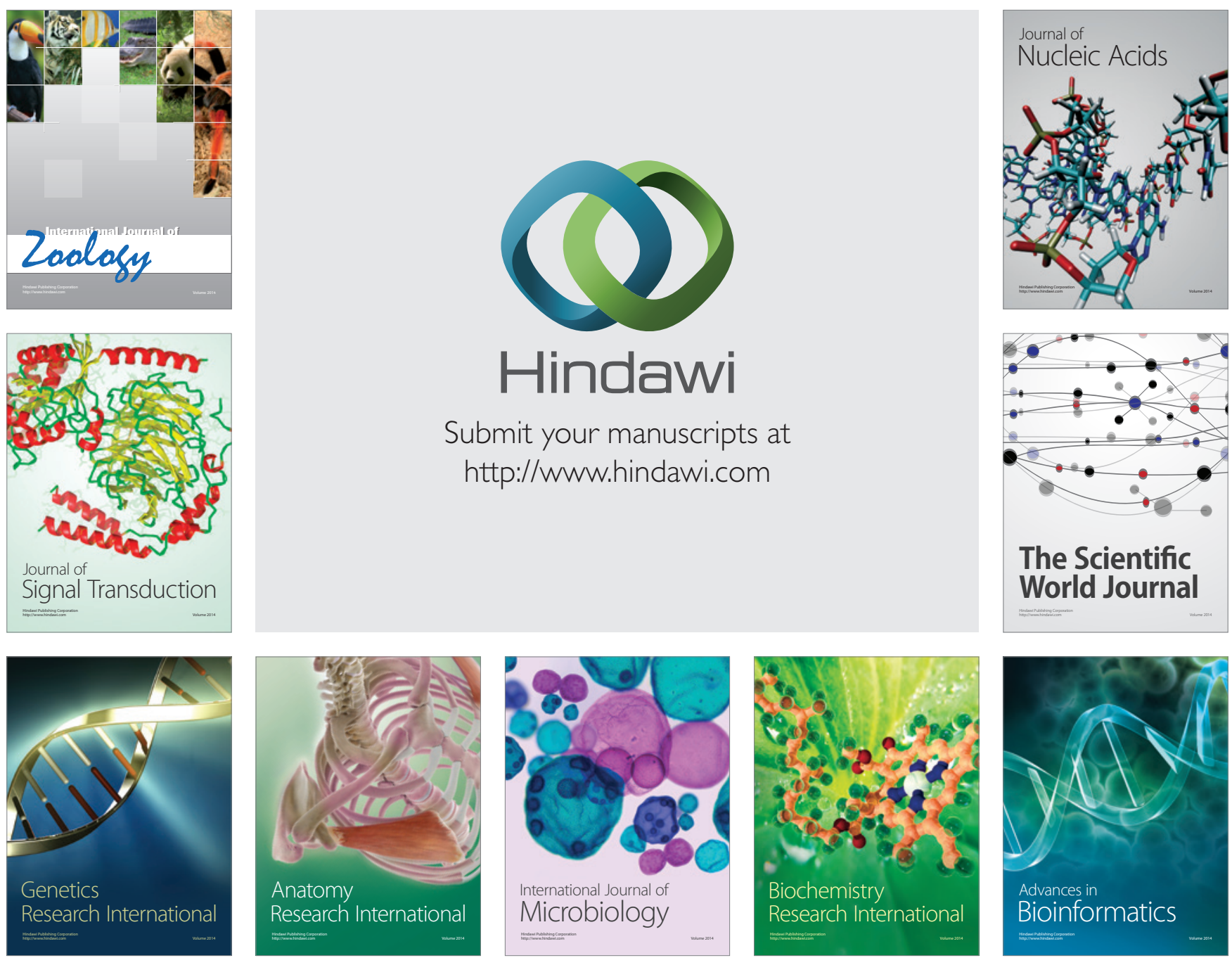

The Scientific World Journal
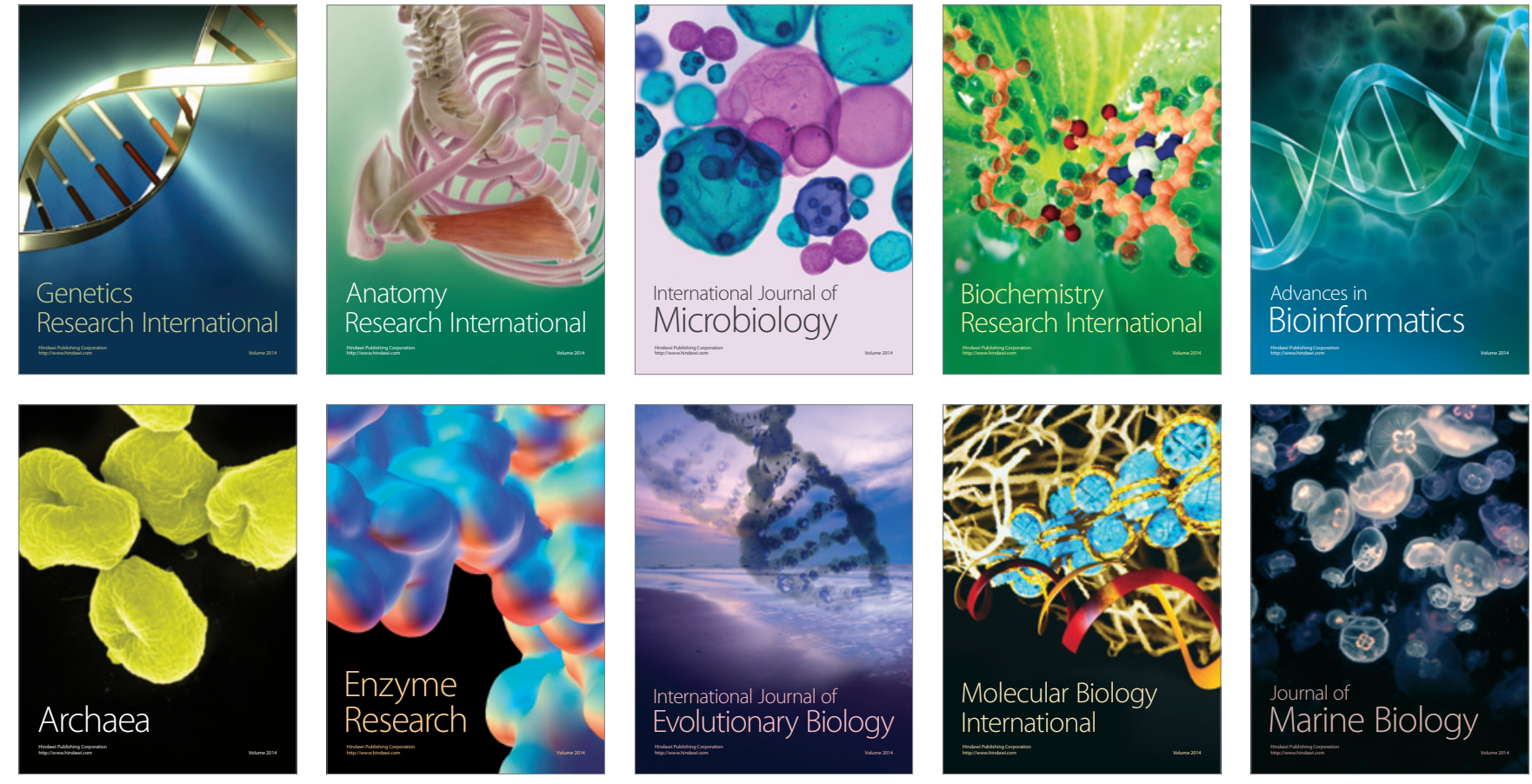